\title{
Teaching Japanese Honorifics Based on Situational Approach
}

\author{
Junjie Xing* \\ Dalian Jiaotong University Dalian 116203, Liaoning, China
}

\begin{abstract}
Japanese honorifics are essential language tools that Japanese people often use in communication. The use of these honorifics is extensive especially in Japanese business settings. Hence, to improve students' proficiency, Japanese language teachers need to emphasize on the education of Japanese honorifics, in addition to implementing the situational approach in their lessons. This article investigates and analyzes the development of Japanese honorifics as well as to propose effective strategies for the implementation of the situational approach in this aspect, in hope to promote the progress of Japanese language education.
\end{abstract}

Keywords: Situational teaching; Japanese honorifics; Teaching strategies

Publication date: May, 2021; Publication online: 31 May, 2021

*Corresponding author: Junjie Xing, starhero1017@163.com

\section{Introduction}

The ability of students to use proper Japanese honorifics reflects on their Japanese proficiency and literacy. Hence, Japanese language teachers play important roles to design teaching activities and reinforce the research of the situational approach by implementing them in Japanese honorifics lessons. In this way, the students' understanding of Japanese honorifics would improve and eventually, help them to master its' use in various situations. Thus, effectively improve the language proficiency among students.

\section{The Development of Japanese Honorifics}

The use of Japanese honorifics reflects the relationship between people. Japanese people rarely use honorifics when communicating with familiar individuals. However, with distant individuals, they tend to use honorifics. It is known that Japanese people have a strong sense of "harmony," hence, they tend to advocate this concept. Japan is an island country and according to historical records, the Japanese people did not communicate with the outside world until the beginning of the $20^{\text {th }}$ century. Therefore, interpersonal relationships in Japan broadly points to internal relationships. This is the main reason why honorifics are so widely used in Japan. The proper use of honorifics has become a form of "identity" and an elegant art in Japan today.

\section{Effective Strategies for the Implementation of Situational Approach in Teaching Japanese Honorifics}

In regard to learning Japanese honorifics, it is easy for students to memorize the classification and thoroughly understand its' sentence structure. However, in actual communication, students are prone to confusion. There are two main reasons for this. Firstly, by merely memorizing words and its' grammar does not facilitate the use of Japanese honorifics openly. Second, only with the use of Japanese honorifics in actual communication, then, students will have a deep grasp of the subject, hence, internalizing them into their own knowledge system. Therefore, it is necessary for teachers to integrate the situational approach into Japanese honorifics lessons. 
3.1 Role-playing as a fun approach in teaching Japanese honorifics

The use of contextual teaching method by creating and organizing role-plays during Japanese honorifics lessons, encourages students to be more intuitive, develop their understanding as well as to enhance their memory on the subject, and to provide opportunities for students to have a vivid and true learning experience. Role-plays requires full participation from the students; hence, they will naturally devote themselves to the lessons. The process of organizing role-plays in a lesson is shown in Table 1.

Table 1. The process of organizing a role-play teaching lesson

\begin{tabular}{|c|c|}
\hline Process & Contents \\
\hline Assign a task & $\begin{array}{l}\text { Assign corresponding role-playing tasks to students according to the teaching } \\
\text { content. }\end{array}$ \\
\hline Role-play & $\begin{array}{l}\text { Form different groups and create roles for the students while taking into } \\
\text { consideration of their choices. }\end{array}$ \\
\hline Check and feedback & $\begin{array}{l}\text { Divide the students into those groups and allow feedback from the students regarding } \\
\text { their role selection. Then, provide reasonable guidance for the students. }\end{array}$ \\
\hline Demonstration & Students' presentation of their role-play on the podium \\
\hline Summary and evaluation & $\begin{array}{l}\text { After the role-play, teachers should guide each group of students to conduct self- } \\
\text { evaluation and inter-group evaluation. Finally, teachers may provide an objective } \\
\text { evaluation. }\end{array}$ \\
\hline
\end{tabular}

Japan is a country with developed honorifics. There are various ways of expressing a sentence even if it is the exact same one. In a situation whereby individuals need to request for assistance or guidance, the standard and proper use of Japanese honorifics in a conversation may bring about positive emotions in the listener; hence, they will be more willing to offer help.

Generally, the longer a sentence is, the stronger the expression of respect and emotions, hence, greatly improve the listener's mood. ${ }^{[1]}$ Therefore, specifically in Japanese honorifics lessons, teachers should focus on strengthening the students' insight of the Japanese language. For novel students, teachers need to guide them in reviewing and consolidating the use of that language. Teachers may also provide students with opportunities to demonstrate Japanese dialogues as much as possible, in order to form excellent insights in the use of Japanese honorifics in a subtle way.

\subsection{Story-based scenarios to enhance students' learning experience}

Teachers may use textbooks, in addition to their own teaching experiences to create vivid storybased scenarios in teaching Japanese honorifics. This helps to improve students' understanding and stimulate their interests in learning honorifics.

For an example, given a scenario whereby an individual intends to send an e-mail to another person in order to receive a prompt reply for his or her previous e-mail, students are then required to figure out how to phrase the content of the e-mail without sounding rude. ${ }^{[2]}$ In order to further stimulate the students' interest and their thought process, teachers may provide examples of past communication failures in regard to the use of Japanese honorifics. Sufficient time should then be given for students to think through the scenario prior submitting their answers. There are usually three types of answers to that scenario (shown in Table 2). 
Table 2. Answers from students

\begin{tabular}{|l|l|}
\hline \multicolumn{1}{|c|}{ Answers } & \multicolumn{1}{c|}{ Analysis } \\
\hline $\begin{array}{l}\text { 先週お願いした件ですが、ご返事をお願 } \\
\text { いします }\end{array}$ & $\begin{array}{l}\text { The purpose of sending the email is implied in a direct manner, in hope that } \\
\text { the receiver may reply the previous e-mail as soon as possible. There are no } \\
\text { major mistakes in this sentence, however, to ensure that the request sounds } \\
\text { tactful, changing the end of the sentence might be helpful. As an example, “お } \\
\text { 願いいたします,いただけませんでしょうか.” }\end{array}$ \\
\hline $\begin{array}{l}\text { メールが届いたはずですが、ご返事のほ } \\
\text { どをお願いします。 }\end{array}$ & $\begin{array}{l}\text { The first half of the sentence explains that that the previous e-mail should } \\
\text { there are no grammatical errors, however, it is abrupt and blunt. The change } \\
\text { of “はず” into “ょうだ” may be more polite, and in line with the standard } \\
\text { use of Japanese honorifics. }\end{array}$ \\
\hline $\begin{array}{l}\text { Alike the second example, changing “はず” into “ょうだ” may be more } \\
\text { polite and appealing. Hence, teachers may guide students to learn to express } \\
\text { in this way. }\end{array}$ \\
\hline
\end{tabular}

\subsection{Integrating the understanding of Japanese culture into lessons}

In every country, languages are developed under the influence of social customs and economic growth. Therefore, the language of each nation has its own characteristics based on the country's identity. The same is true in context of the Japanese language, whereby Japanese honorifics are closely related to the Japanese culture. ${ }^{[3]}$ For students to learn proper Japanese honorifics, they need to understand the Japanese culture first. Therefore, teachers should integrate the discussion of Japanese culture into their lessons, in order for students to improve their understanding of Japanese values, behaviors, and cultural characteristics. Teachers may then use multimedia equipment for students to better understand the Japanese culture. For example, to understand the Japanese workplace culture, teachers need to enlighten their students that it is a common practice for a new employee to understand his or her position in the company and make every effort to form harmonious relationships with everyone in the company. In addition to that, when it comes to social behaviors, Japanese people place emphasis on considering other people's thoughts and emotions first. Hence, Japan is also known as an "ambiguous nation" in regard to their modernization yet maintaining traditional cultures in their everyday life. Japanese honorifics that are often used are shown in Table 3.

On the other hand, in China, these are also common honorifics used in the service industry, indicating that there are similarities between the Japanese and Chinese cultures. ${ }^{[4]}$ Integrating Japanese culture into teaching lessons allows students to intuitively recognize similarities and differences between the Japanese and Chinese culture, in addition to enhancing students' intercultural awareness. Hence, this would benefit the students' learning process in mastering Japanese honorifics.

Table 3: Commonly used Japanese honorifics in various settings

\begin{tabular}{|l|l|}
\hline \multicolumn{1}{|c|}{ Commonly used honorifics } & \multicolumn{1}{c|}{ Settings } \\
\hline いらっしゃいませ & $\begin{array}{l}\text { This means "Welcome." The honorifics seen in this phrase are often used in the } \\
\text { service industry. }\end{array}$ \\
\hline おはようございます & $\begin{array}{l}\text { This means "Good morning." The honorifics seen in this phrase are used between } \\
\text { colleagues at work or at business settings. }\end{array}$ \\
\hline おまたせいたしました & $\begin{array}{l}\text { This means "Sorry to keep you waiting." This is also a common honorific phrase } \\
\text { used in the service industry. }\end{array}$ \\
\hline
\end{tabular}




\section{Conclusion}

In summary, Japanese honorifics are important in the learning of the Japanese language. Teachers need to emphasize on the education of Japanese honorifics, break off from ancient teaching methods, and implement the situational teaching approach in order to offer students a more intuitive and vivid learning experience. Eventually, the students' sense of using Japanese honorifics would be enhanced. In the context whereby teachers prepare their lessons based on standard curriculums with unique teaching methods, student-centered learning is also important. Teachers should consider the students' attributes and individual needs to effectively improve their Japanese proficiency.

\section{Disclosure statement}

No conflicts of interest.

\section{References}

[1] Yi, H(2019). Analysis of the specific application of self-humility and respect in Japanese teaching as a second foreign language in university. Modern Communication, (19): 19-20.

[2] Han, X(2019). A Quantitative Investigation of Japanese Honorific Verbs Based on "Hotel Concierge" and Its Teaching Enlightenment. Journal of Xi'an International Studies University, 27(02): 108-113.

[3] Ting, W(2019). Exploration of Japanese honorific teaching methods at the elementary stage. Science Education Journal (Early Issue), (01): 120121.

[4] Sa, Y(2018). A probe into the Japanese honorific teaching method - combined with the "can-do" mode in the JF Japanese Standard. Education Teaching Forum, (16): 213-215. 